\title{
THE EFFECT OF PSYCHOLOGICAL CONTRACT VIOLATION ON THE SATISFACTION OF BASIC PSYCHOLOGICAL NEEDS
}

\author{
Devani Laksmi Indyastuti \\ Faculty of Economics, Jenderal Soedirman University \\ Devani20092010@gmail.com
}

\begin{abstract}
This study aims to examine the effect of violations of psychological contracts on satisfaction of basic psychological needs. Basic psychological needs consist of a sense of autonomy, competency and connectedness. Data were obtained from a sample of teachers and staff in schools in Purwokerto. The research method used a survey. The results showed that it is important for school administrators to pay attention to the employee psychological violations. Based on the research results showed that psychological contract breach effects the autonomy and connectedness of a person, but not the competence.
\end{abstract}

Keywords: psychological contracts, autonomy, competency and connectedness

\begin{abstract}
Abstrak
Penelitian ini bertujuan untuk menguji pengaruh pelanggaran kontrak psikologis terhadap kepuasan kebutuhan psikologis dasar. Kebutuhan psikologis dasar terdiri dari rasa otonomi, kompetensi dan keterhubungan. Data diperoleh dari sampel guru dan staf di sekolah-sekolah di Purwokerto. Metode penelitian menggunakan survei. Hasil penelitian menunjukkan bahwa penting bagi administrator sekolah untuk memperhatikan pelanggaran psikologis karyawan. Berdasarkan hasil penelitian menunjukkan bahwa pelanggaran kontrak psikologis berdampak pada otonomi dan keterhubungan seseorang, tetapi tidak pada kompetensi.
\end{abstract}

Keywords: kontrak psikologis, otonomi, kompetensi dan keterhubungan

JEL: M12

\section{Research Background}

Psychological contract is individual beliefs about agreements of two-way exchanges about conditions and problems between individuals and other parties (Robinson, 1996). Violation of the psychological contract is an individual perception that organization has failed to fulfill its obligations under one or more of the psychological contracts relating to the individual contributions (Morrison \& Robinson 1997).

Various impacts can be appeared by violations of psychological contracts, such as trust in the organization, affective commitment, intention to leave the organization (Dulac, Saphiro \& Handerson 2008). However, research on the impact of violating psychological contracts on satisfaction of basic psychological needs has not received the attention of academics. Violating contract will certainly affect the emotional, psychological distress, negative sense, feeling betrayed and psychological individual, including affecting satisfaction of basic psychological needs of individuals. This study wants to check the influence of psychological contract violations against the three basic psychological needs, namely autonomy, competency, and connectedness. This test is conducted because this model has not been done in previous research. 
Competency, autonomy and connectedness are basic psychological needs that humans have since birth (Gagne \& Deci 2005). This need must be fulfilled, so that human activities run smoothly. The fulfilment of this need causes individual performance about to increase (Gagne $\&$ Deci, 2005). Passion and desire can arise when these three needs are met.

Epitropaki (2013) argues that violations of psychological contracts will lead to individual perceptions of how the organization does not meet the basic needs of members of its organization. The difference between expectations and reality given causes individuals to have perceptions that are not in accordance with the contributions given. In the long term, this perception led higher pressure psychologically for the individual. This pressure will reduce the sense of autonomy and uncertainty that will reduce individual competencies. Gagne and Deci (2005) reveals that pressure affects the sense of autonomy and reciprocity will affect individual's competency. A good relationship will also influence the sense of individual connectedness (Gagne \& Decy 2005). Based on this argument, this research aims to examine the negative influence of psychological contract violation to the sense of autonomy, competency and connectedness.

Self determination theory states that humans have basic psychological needs that have to be fulfilled, by that all activities can run smoothly (Deci \& Ryan 2008). This is because psychological fulfilment of the individual will affect an individual's mental health, happiness, and comfort. If it could not be filled, it causes an individual to become anxious, unhappy and anxious (Ryan \& Deci 2002). This feeling will inhibit the daily activities. These basic psychological needs are a sense of autonomy, competency and connectedness. Autonomy is the feeling that what he does is based on his own desires (Ryan \& Deci 2002). Competence is the feeling that an individual is able to overcome challenging problems (Ryan \& Deci 2002). Connectedness is a feeling that he is part of his community (Ryan \& Deci 2002).

Skinner and Edge (2002) state that conditions will support the fulfilment of basic psychological needs. They specify that hostility, hatred will decrease the sense of connectedness, psychological pressure will decrease the sense of autonomy, uncertainty between returns and individual contributions will decrease competency. The researcher argues that violations of psychological contracts will affect a sense of autonomy, competency and connectedness.

This study proposes that psychological behavior violations will affect the sense of autonomy, competency and connectedness. Violations of psychological contracts give rise to individual negative feelings that have been violated by their contracts (Conway \& Briner 2005). These negative feelings lowered the sense of connectedness. Psychological contract violations also cause uncertainty between returns connection to individuals after they contribute. Skinner and Edge (2002) state that unclear returns lead to decreased sense of competency. Continuous psychological contract violation will also lead to a negative feeling that eventually led to feelings of distress. Skinner and Edge (2002) state that pressure will cause a sense of autonomy to decrease. Based on the above argument the researcher hypothesized as follows: H1: Violations of Psychological Contracts Have Negative Effects on the Sense of Autonomy; H2: Violation of Psychological Contracts Negatively Affects the Sense of Competence; H3: Violation of Psychological Contracts has a Negative Effect on the Sense of Connectedness.

\section{Research Method}

This study took samples of teachers and staff in high school, junior high and elementary schools in Purwokerto, Central Java. The samples taken in this study were 138 respondents. The number of respondents is 109 teachers and 29 administrative staff. There were 88 female respondents and 50 male respondents. 
All variables in this study were measured by Likert scale with a scale between 15. Values of autonomy, competency, and connectedness measured by instrument developed by Van den Broeck, Vansteenkiste, De Witte, Soenens, and Lens (2010). Psychological contract violations use instruments developed by Robinson and Morrison (2000).

\section{Result and Discussion}

Table 1. Showing descriptive analysis for psychological contract violation variables, autonomy, competency and connectedness.

Table 1. Descriptive analysis

\begin{tabular}{lllllll}
\hline Variable name & Mean & $\begin{array}{l}\text { Standard } \\
\text { Deviation }\end{array}$ & $(1)$ & $(2)$ & (3) & (4) \\
\hline $\begin{array}{l}\text { (1) Psychological } \\
\quad \text { contract violations }\end{array}$ & 2,455 & 0.572 & 1 & & & \\
(2) Autonomy & 3,561 & 0.453 & $-0,295 * *$ & 1 & & \\
(3) Competency & 3,948 & 0.503 & -0.124 & $0.376 * *$ & 1 & \\
(4) Connectedness & 3,808 & 0.397 & $-0,183 *$ & $0.522 * *$ & $0,369 * *$ & 1 \\
\hline
\end{tabular}

* significant $<0.05$

$* *$ significant $<0.001$

Based on the table above, it can be seen that all variables have a significant correlation except competency variables and psychological contract violations. Independent variables also have significant correlations with one another. This correlation could happen because those three values is categorized in a kind of needs that is basic human psychological demand.

Table 2. Showing the results of the analysis to test the hypotheses proposed.

Table 2. Regression Analysis of Hypothesis Testing

\begin{tabular}{|c|c|c|c|c|c|c|}
\hline \multirow[t]{2}{*}{ Independent Variables } & \multicolumn{6}{|c|}{ Dependent variable } \\
\hline & \multicolumn{2}{|c|}{ Autonomy } & \multicolumn{2}{|c|}{ Competency } & \multicolumn{2}{|c|}{ Connectedness } \\
\hline Violation of Psychological Contracts & $\begin{array}{c}\beta \\
-0,295 * *\end{array}$ & $\begin{array}{c}\mathrm{t} \\
-3,595\end{array}$ & $\begin{array}{c}\beta \\
-0.124\end{array}$ & $\begin{array}{c}\mathrm{t} \\
-1,452\end{array}$ & $\begin{array}{c}\beta \\
-0,183 *\end{array}$ & $\begin{array}{c}\mathrm{t} \\
-2,166\end{array}$ \\
\hline Significant at $\rho<0.05$ & & & & & & \\
\hline
\end{tabular}

Based on the results of the analysis presented by Table 2, hypothesis 1 is supported by the results of the study. Violations of psychological contracts negatively affect the sense of autonomy. The pressures caused by violation of contract cause a sense of individual autonomy reduced.

Hypothesis 2 in this study is not supported. Psychological contract violations have no effect on competency. In the context of this research, the sense of individual competency is not affected by violations of the psychological contract of the school manager. This is because of the competency of teachers and staff are more influenced by other things rather than the disappointing behavior given by the school management.

Hypothesis 3 is supported by the results of this study. Violations of psychological contracts have a negative effect on feelings of connectedness. It causes negative feelings and emotions towards the school manager, as result the sense of connectedness is about to be lowered. Then, the violation brings negative feelings and emotional reactions toward the organization (Robinson \& Morrison 2000). This feeling gives rise to a sense of connectedness decreasing. 


\section{Conclusion}

Psychological contract violations have a negative effect on a sense of autonomy and connectedness. Robinson and Morisson (2000) state that violations of psychological contracts give rise to negative feelings and even emotional reactions to the organization. This feeling will decrease the sense of connectedness. Skinner and Edge (2002) state that the atmosphere of a social environment that is not warm will reduce a sense of connectedness. This argument is supported by the results of this research.

Erratic psychological contract violations cause an ongoing emotional reaction that causes psychological distress. This psychological pressure causes a sense of autonomy to be reducted.

However, this research does not support the hypothesis that violations of psychological contracts reduce the sense of competence. Researchers argued that there might be other factors that influence the sense of competence, so that the effect of violating psychological contracts on competency was not apparent in this study. Values of competence in this study is quite high but it is not explained by psychological contract violation. This is the reason for the researchers' argument that the sense of competency is more influenced by other factors because in this study the factors that were not observed were not controlled.

\section{References}

Conway N, Briner RB. 2005.Understanding Psychological Contracts at Work. Oxford: Oxford University Press.

Deci EL, Ryan RM 2008. Facilitating Optimal Motivation and Psychological Well-Being Across Life 's Domains. Canadian Psychology. 49(1): 14-23.

Dulac T, Coyle-Shapiro JAM, Henderson DJ, Wayne SJ 2008. Not All Responses to Breach Are the Same: The Interconnection of Social Exchange and Psychological Contract Processes in Organizations. Academy of Management Journal. 51: 1079 - 1098.

Epitropaki O. 2013. A Multi-level Investigation of Psychological Contract Breach and Organizational Identification Through the Lens of Perceived Organizational Membership: Testing A Moderated - Mediated Model. Journal of Organizational Behavior. 34: 65 - 86

Gagne M, Deci EL. 2005. Self Determination Theory and Work Motivation. Journal of Organizational Behavior. 26: 331-362.

Morrison EW, Robinson SL. 1997. When Employees Feel Betrayed: A Model of How Psychological Contract Violation Develops. Academy of Management Review. 22: 226 256.

Ryan RM, Deci EL. 2002. Overview of Self Determination Theory: An Organismic Dialectical Perspective. New York: The University of Rochester Press.

Robinson SL. 1996. Trust and Breach of The Psychological Contract. Administrative Science Quarterly. 41: 574-599.

Robinson SL, Morrison EW. 2000. The Development of Psychology in Contract Breach and Violation: A Longitudinal Study. Journal of Organizational Behavior. 21: 525- 546.

Skinner E, Edge K. 2002. Self Determination, Coping and Development. New York: University of Rochester Press.

Van den Broeck A, Vansteenkiste M, De Witte H, Soenens B, Lens W. 2010. Capturing Autonomy, Competence, and Related Work at the Construction and Initial Validation of Work-Related Basic Need Satisfaction on Scale. Journal of Occupational and Organizational Psychology. 83: 981-1002. 